\title{
MASTER
}

\section{PATHFINDER ATOMIC POWER PLANT MEASUREMENTS OF NUCLEAR PARAMETERS \\ BOILER AND SUPERHEATER LATTICES}

AUGUST 31, 1959

\section{Submitted to}

U. S. ATOMIC ENERGY COMMISSION NORTHERN STATES POWER COMPANY

and

CENTRAL UTILITIES ATOMIC POWER ASSOCIATES by

ALLIS-CHALMERS MANUFACTURING COMPANY ATOMIC ENERGY DIVISION

Milwaukee 1, Wisconsin

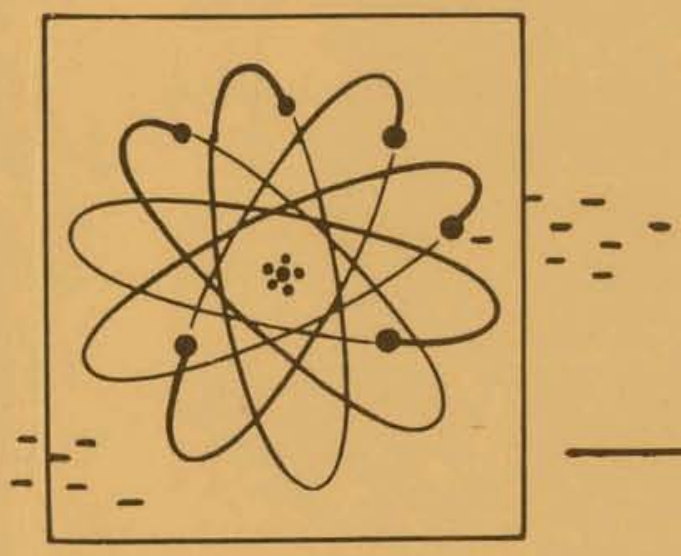

Ref: AEC Contract No. AT(11-1)-589 


\section{DISCLAIMER}

This report was prepared as an account of work sponsored by an agency of the United States Government. Neither the United States Government nor any agency Thereof, nor any of their employees, makes any warranty, express or implied, or assumes any legal liability or responsibility for the accuracy, completeness, or usefulness of any information, apparatus, product, or process disclosed, or represents that its use would not infringe privately owned rights. Reference herein to any specific commercial product, process, or service by trade name, trademark, manufacturer, or otherwise does not necessarily constitute or imply its endorsement, recommendation, or favoring by the United States Government or any agency thereof. The views and opinions of authors expressed herein do not necessarily state or reflect those of the United States Government or any agency thereof. 


\section{DISCLAIMER}

Portions of this document may be illegible in electronic image products. Images are produced from the best available original document. 


\section{LEGAL NOTICE}

This report was prepared as an account of Government sponsored work. Neither the United States, nor the Commission, nor Allis-Chalmers Manufacturing Company, nor any person acting on behalf of the Commission or Allis-Chalmers Manufacturing Company:

A. Makes any warranty or representation to others, expressed or implied, with respect to the accuracy, completeness, or usefulness of the information contained in this report, or that the use of any information, apparatus, method, or process disclosed in this report may not infringe privately owned rights; or

B. Assumes any liabilities to others with respect to the use of, or for damages resulting from the use of any information, apparatus, method, or procass disclosed in this report.

As used in the above, 'person acting on behalf of the Commission or AllisChalmers Manufacturing Company' includes any employe or contractor of the Commission, or Allis-Chalmers Manufacturing Company or employe of such contractor, to the extent that such employe or contractor of the Commission, or Allis-Chalmers Manufacturing Company or employe of such contractor prepares, disseminates, or provides access to, any information pursuant to his employment or contract with the Commission or Allis-Chalmers Manufacturing Company or his employment with such contractor. 


\title{
ALLIS-CHALMERS MANUFACTURING COMPANY \\ ATOMIC ENERGY DIVISION \\ MILWAUKEE I, WISCONSIN
}

\begin{abstract}
PATHFINDER
ATOMIC POWER

PLANT
\end{abstract}

\author{
MEASUREMENTS OF NUCLEAR PARAMETERS \\ OF
}

BOILER AND SUPERHEATER LATTICES

This report covers work performed under Allis-Chalmers Manufacturing Company's Purchase Order No. WA-357918-NSP, a part of the Research and Development program under AEC Contract No. AT $(11-1)-589$ with Northern States Power Company

August 31, 1959

by

Alan Jacobs

Pennsylvania State University<smiles>C=C[As]</smiles>
University Park, Pennsylvania

and
$:$
R. H. Voll mer
Nuclear Power Department-Greendale
$04,4^{3 b}$
All is-Chalmers Manufacturing Company
Milwaukee 1, Wisconsin 


\section{PATHFINDER ATOMIC POWER PLANT \\ Measurements of Nuclear Parameters of \\ Boiler and Superheater Lattices}

\section{Distribution}

USAEC, Chicago Operations office $\ldots \ldots \ldots \ldots \ldots \ldots \ldots \ldots \ldots \ldots$

USAEC, Dịvision of Reactor Development $\ldots \ldots \ldots \ldots \ldots \ldots \ldots \ldots$. 8

USAEC, TISE .................... "Offset Master" plus 20

Northern States Power Company and ICUAPA ............... 35

Allis-Chalmers Manufacturing Company ................ 39

Total Copies ............ 110 
MEASUREMENTS OF NUCLEAR PARAMETERS

OF BOILER AND SUPERHEATER LATTICES

\section{PURPOSE OF MEASUREMENTS}

This set of experiments was designed to yield information pertinent to the evaluation of the nuclear parameters (such as thermal utilization, resonance escape, and void reactivity coefficients) of various fuel-moderator lattices in the environment of the controlled recirculation boiling reactor (CRBR) core. The neutron source used in the measurements was a suitable configuration of The Pennsylvania State University Research Reactor (PSR) core. The test lattice section was enclosed in an element which replaced one of . the fuel elements of the PSR.

The purpose of the measurements was to obtain information for the evaluation of:

I. Boiling water lattice parameters.

a. Resonance escape probability, p.

b. Thermal neutron utilization, $f$.

c. Void reactivity coefficient, $\gamma_{v}$.

2. Low enrichment superheater lattice parameters.

a. Resonance escape probability, $p$ :

b. Thermal utilization, f.

c. Flooding reactivity coefficient, $\gamma_{f}$.

3. High enrichment superheater lattice parameters.

a. Thermal utilization, f.

b. Flooding reactivity coefficient, $\gamma_{f}$. 


\section{EXPERIMENTAL PROCEDURES}

The experimental measurements described in this section were performed at the PSR facility and assoclated radiochemical laboratories during the period from July, 1958 to May, 1959. The parameters measured were:

1. Uranium-238 neutron capture cadmium ratio, R,

2. Space-averaged thermal neutron flux ratios, $\bar{\phi}$, and

3. Reactivity coefficients, $\gamma$.

For each of these measurements, a test element, containing a section of the desired CRBR lattice with lucite and/or water acting as moderator, was placed in the PSR core. Two PSR core configurations were employed during the experiments. These are illustrated in Figure $I$ and are designated PSR core $A$ and PSR core $B$. Figure 11 is a photograph of the complete test element can in which the various CRBR lattices were placed for insertion iñto the PSR core.

Uranium-238 neutron capture cadmium ratio:

Natural and depleted (NS-40) uranium foils, of 0.005 inch thickness and fuel pin cross section, were exposed to the fuel flux. Cadmium difference measurements were performed using cadmium covers of 0.020 inch thickness. The arrangement of the foils is illustrated in Figure 111 . Figures IV and $V$ are photographs of the boiling water lattice test section and foil holding pin respectively. In both low enrichment lattices, as illustrated in Figure 111 , for the cadmium covered foil, fuel spacers were used between the sensing foil and the horizontal cadmium covers to prevent streaming of the enhanced uranium-238 resonance flux of the moderator. One-eighth and one-quarter inch thick spacers were employed in initial measurements, but no significant difference in the cadmium 
ratio, $R$, resulted. Thus, in the remaining measurements, only the smaller spacer sections were employed due to the resulting smaller cadmium vertical side cylinder covers.

The interaction utilized in the determination of $R$ was

$$
\mathrm{n}+\mathrm{U}^{238}=\mathrm{U}^{239} \longrightarrow \beta^{-}(23.5 \mathrm{~min})
$$

and the uranium-239 electron emission rate was counted. Because of the high fission product background from the uranium-235 fission, the irradiated uranium was separated from the fission products by the sodium uranyl acetate method (see Appendix A for details). In order to eliminate the necessity of calculating sample thickness and physical disposition effects on the self-absorption of emitted electrons, the "thick sample" method was used. The sample consisted of a $0.5 \mathrm{~cm}$ thick by $2.5 \mathrm{~cm}$ diameter water solution of from about 0.05 to 0.1 grams of sodium uranyl acetate. In Figure VI the general counting configuration is illustrated. The beta activity was counted over a period of about one-half hour for each sample to determine the half-life. This halflife was compared with the expected 23.5 minute activity.

Bare foil and cadmium covered foil irradiations were identical. For the particular separation method and sample size employed, it was found that a ten minute irradiation at a test section thermal neutron flux level of about $10^{8}$ per $\mathrm{cm}^{2}-\mathrm{sec}$ yielded good counting rates. The PSR core configurations and CRBR lattice moderator dispositions used in these measurements were:

1. Boil core lattice.

A. Full density lucite; PSR core B.

B. 14.4\% void in lucite; PSR core B. 
2. Low enrichment superheater lattice.

A. Steam channels linflnnderl; PSR conre R;

B. Steam channels flooded; PSR core B.

Space-averaged thermal neutron flux ratios:

Uranium-235-aluminum al loy foils (about $2 \%$, by number density, uranium-235) of 0.005 inch thickness were exposed to various lattice section fluxes to obtain space-averaged thermal neutron flux ratios. The fission product gamma emission was sensed by counting only gammas with energy above $400 \mathrm{Kev}$. A convenient calibration source for the $\mathrm{Nal}$ crystal spectrometer used is the 2.7 day, $412 \mathrm{Kev}$ gamma from Aul99 activity. In Figure VII the foil sections used for the three CRBR lattices are depicted. The foil sections are necessarily symmetric for purposes of interpretation (see section IV of this report). The PSR core configurations and CRBR lattice moderator dispositions used in these measurements were:

1. Boiler core lattice.

A. Full density lucite; PSR core A.

B. $14.4 \%$ void in lucite; PSR core $B$.

2. Low enrichment superheater lattice.

A. Steam channels unflooded; PSR core B.

B. Steam channels flooded; PSR core B.

3. High enrichment superheater lattice.

A. Steam channels unflooded; PSR core B.

B. Steam channels flooded; PSR core B.

If the uranium-235 was uniformly dispersed in the alloy material, then it would only be necessary to normalize the various foil section activities by the foil weight. In the present case, this was not the 
situation; thus the foil sections were also irradiated in a uniform thermal neutron flux by means of a cylindrical graphite rotating plug on which the foils were placed in a plane of rotation. This uniform flux irradition provided a means of intercalibration of foils.

In both the lattice irradiation and the normalization irradiations, the fission product activity does not follow a simple exponential temporal function. In the present measurements this difficulty was averated by counting the series of section foils (all irradiated at the same time) in succession several times and then determining the temporal curve for each foil section. If this is done correctly, then at all times, after irradiation the foil activities will be in the same ratio. In the case of the boiling water lattice the sensing foils were sectioned before irradiation. For the other lattices the foils were cut into the sections illustrated in Figure VII after irradiation in the lattice. Of course, in both cases the foil sectioning occurred before the normalization irradiations.

Reactivity coefficients:

For measurement of both voiding and flooding coefficient of reactivity the "inhour method" was used. That is, after the critical rod positions were found, the desired change in test element was accomplished. Then the resulting change in position, of a previously reactivity calibrated rod, necessary to maintain a critical condition yields the reactivity worth of the particular test element modification. of course, this reactivity worth is valid only for the small section of the CRBR lattice in a particular position in the PSR core. The interpretation of these results are presented in section IV. 
In the case of the void coefficient for the boiler core lattice the following reactivity measurements were performed:

1. $14.4 \%$ uniform void in lucite of central test section; PSR core B.

2. Four strips of indium ( 4.00 grams; total) in fuel channels with 14.4\% vold; PSR core B.

The moderator void was produced by drilling holes (ca: I/8 inch diam.) in the lucite sections. Figure VIII is a photograph of one of the voided lucite sections: The CRBR boiler lattice only occupied the central onethird of the test element. The two outer thirds of the test element were filled with solid lucite blocks. These outer sections were not modified in the void coefficient measurement.

For the superheater lattices, as pictured in Figure IX, there was sufficient cross sectional area of the test element for only approximately four unit lattice cells (i.e., four fuel channels with associated moderator and steel sections). In the case of the low enrichment superheater lattice the reactivity measurements performed were:

1. Flooding of four outer stearn channels; PSR core A.

2. Flooding of all steam channels; PSR core A.

3. Four strips of indium (23.7 grams), one in each unflooded fuel channel; PSR core A.

The flooding was accomplished by insertion of the lucite outer steam channel sleeves and the lucite inner steam channel rods. Unflooded fuel pins were positioned by narrow aluminum sleeves at the pin ends. 
Because of the difficulty encountered in attempts to remove and replace the lucite sections occupying the steam channels of the high enrichment superheater lattice, flooding was accomplished by the introduction of water (one gram per $c c$ ) into the steam channels. Lucite remained in the position of the moderator channels. The measurements performed for the high enrichment superheater lattice were:

1. Flooding (with water) of all steam channels; PSR core A.

2. Four strips of indium (12.1 grams), one in each unflooded fuel channel; PSR core A.

3. Four strips of indium (12.1 grams), one in each flooded fuel channel; PSR core A.

\section{RESULTS OF MEASUREMENTS}

The following list of results are based only on those experimental trials where no obvious error was committed. The uncertainties presented are estimates of the maximum expected uncertainties determined from the maximum variation in the particular parameter results over several trials on the same lattice configuration. Any deviations greater than those quoted were attributed to definite and obvious errors in experimental procedure. In Figure $X$, the dimensions of the full CRBR unit lattices are illustrated for the three cases under study. As mentioned earlier in this report, full fuel cross section foils were used in $R$ measurements. The thermal flux foil sections quoted refer to those illustrated in Figure VIl.

Boiler core lattice:

\begin{tabular}{clll} 
Parameter & $\frac{\text { Value }}{\text { Vall Lucite condition }}$ & $\begin{array}{c}\text { Test pin } \\
\text { location* }\end{array}$ \\
\hline$R$ & $1.87 \pm .04$ & Full density & Center \\
$R$ & $1.91 \pm .04$ & Full density & Off-center \\
$R$ & $1.70 \pm .05$ & $14.4 \%$ void & Center \\
$\gamma_{V}$ & -.00034 & $14.4 \%$ void (end condition) - \\
$\gamma_{\text {in }}$ & -.00057 & $14.4 \%$ void & -
\end{tabular}

* See section IV of this report for precise locations. 
Thermal neutron flux averages (center location).

Foil Value (full density lucite) value (14.4\% void lucite)

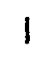

2

$$
1.00 *
$$

$1.08 \pm .02$
$1.00 *$

$1.09 \pm .02$

Low enrichment superheater lattice:

\begin{tabular}{|c|c|c|c|}
\hline Parameter & Value & Outer steam channel & Inner steam channel \\
\hline$R$ & $1.90 \pm .04$ & Unflooded & Unfl looded \\
\hline $\mathrm{R}$ & $2.11 \pm .04$ & Flooded & Flooded \\
\hline$\gamma_{f}$ & .00046 & Flooded (end condition) & Unflooded \\
\hline$\gamma_{f}$ & .00113 & Flooded (end. condition) & Flooded (end condition) \\
\hline$\gamma_{\ln }$ & -.00094 & Unflooded & Unflooded \\
\hline Therma ! & neutron flux & averages. & \\
\hline Foil & Value (st & team channels unflooded) & Value (steam channels flooded) \\
\hline 1 & & 1.00 & 1.00 \\
\hline 2 & & $1.01 \pm .02$ & $0.91 \pm .02$ \\
\hline 3 & & $1.08 \pm .02$ & $0.97 \pm .02$ \\
\hline 4 & & $1.28 \pm .02$ & $1.12 \pm .02$ \\
\hline
\end{tabular}

High enrichment superheater lattice:

$\begin{array}{ccc}\text { Parameter } & \text { Value } & \text { Steam channels } \\ \gamma_{f} & .00178 & \text { Flooded (end condition) } \\ \gamma_{\text {In }} & -.00054 & \text { Flooded } \\ \gamma_{\text {In }} & -.00035 & \text { Unflooded }\end{array}$

* Normalized to this value. 
Thermal neutron flux averages.

Foll Value (steam channels unflooded) Value (steam channels flooded) 1

2

3

1.00

.00

2

4

4

5

$$
1.03 \pm .02
$$

$0.98 \pm .02$

3

$$
1.06 \pm .02
$$

$1.02 \pm .02$

4

$$
1.10 \pm .02
$$$$
1.09 \pm .02
$$

$$
1.12 \pm .02
$$

$1.11 \pm .02$

6

$$
1.27 \pm .02
$$

$1.15 \pm .02$

\section{INTERPRETATION OF EXPERIMENTAL RESULTS}

The interpretation of the cadmium ratio results has been done adequately for the case of the boiler lattice, but is less direct for the case of the low enrichment superheater lattice. Since only about four unit lattice cells of the superheater lattice could be placed in the test element, the effects of adjacent fuel pin "shading" for resonance neutrons are not reproduced. In the case of the boiler core lattice section, twenty-five unit lattice cells were placed in the test element and thus the effects of adjacent fuel pin "shading" are well developed by the central pin (in fact, these effects are like the infinite lattice in the second row of fuel pins). The following considerations are, thus, restricted to the case of the boiler lattice.

The theoretical problem which provided the incentive for the measurement of $R$ is the calculation of the resonance escape probability, $p$, for "tight" lattices. If it is assumed that there is no net leakage from the unit lattice cell in which measurements are performed, then $p$ (for uranium-238 resonance capture) is given by the expression:

$$
p=\left[1+\left(\frac{1}{R-1}\right) \frac{\sum_{a}^{28}}{\sum_{a}^{f}} t\right]^{-1}
$$


where $\Sigma_{a}$ are thermal absorption cross sections, $F$ denotes fuel, f is the thermal utilization, and $R$ is the uranium-238 cadmium ratio (i.e. ratio of resonance plus thermal absoption to resonance absorption). The thermal utilization can be determined from the spatial average flux measurements which require little detailed interpretation (see below). The result of the present measurement of $R$, however, is not valid for the CRBR environment because of the fraction of epithermal neutrons in the test section which originated in fission in the PSR core elements, and the spectral differences between the two cores. Therefore, the results of these measurements cannot be used directly to evaluate $p$ for the CRBR core. However, they can be used to determine resonance neutron group cross section for uranium-238 capture to be used in multi-group, diffusion theory calculations. A one-dimensional, nineteen energy group calculation was performed on the contiguration:

$\begin{array}{crcc}\text { PSR } & \text { Test element } & \text { PSR } & \text { Water reflector } \\ 10 \mathrm{~cm} . & 7.3 \mathrm{~cm} . & 7.6 \mathrm{~cm} . & 20 \mathrm{~cm} .\end{array}$

Using $0.082 \mathrm{~cm}^{-1}$ for the uranium-238 resonance region (groups $i=10$ through $i=14$ ) yielded the results shown in Figure $X 1$. Also included in Figure $\mathrm{XI}$ are the experimental measurements at two fuel pin locations. The resonance group cross section was set at a value which reproduced the central fuel pin measurement. If the reasonable assumption is made that the spatial dependence of the neutron flux at any energy appearing in the inner cells of the test section (boiler lattice) is that which will occur in the CRBR core, then this present approach is a valid method of including pin "shading" and surface absoption effects in resonance group cross sections. Therefore, the combination of the experimental 
measurements and the diffusion calculations, as outlined, will directly yield the applicable value of $p$, the resonance escape probability, for this lattice.

Due to the small dimensions of all the lattice cells under consideration, relative to the rate of thermal neutron flux change with position at the test section location, the interpretation of the integral thermal neutron flux measurements is straight forward. If it is assumed that, over all unit lattice cross sections used in the measurements, the thermal neutron flux decline (exclusive of internal lattice variations) is linear in all directions, then, providing symmetrical foils are employed, the results of spatial average flux variation is that which would be obtained in an infinite array of these unit lattice cells. In terms of these spatial average (or integral) flux ratios the thermal utilization is given by the expression:

$$
f=\left[1+\frac{1}{\sum_{a}^{F}}{ }_{i}^{s} \frac{\int \phi_{i}}{\int \phi_{F}} \Sigma_{a}^{i}\right]^{-1}
$$

where $\sum_{a}$ are thermal absorption cross sections, i refers to non-fue! regions, F refers to fuel region, $\int_{\phi}$ are integral thermal neutron flux over cell regions, and, $i$ denotes summation over cell regions. It should be noted that in the cases of the superheater lattice full section moderator channel foils could not be used due to the restriction of the test element can size.

The analysis of the reactivity coefficient data is complicated by the sensitivity of the $\gamma$ 's to the epithermal to thermal flux ratio and leakage effects. The epithermal to thermal flux ratio in an infinite lattice of the PSR is not the same as in the infinite CRBR lattice, therefore, the effect on $\gamma$ is not directly applicable. Similarly, the size 
of the test sample is such that the leakage effects exhibited are different than in the full scale lattice. However, the $\gamma$ data measured in these experiments may be used to yield information directly applicable to the CRBR lattice in a manner described below. The method is described in two-group notation although extension to multi-group is not difficult. Because of geometric complexity, three, or at least two, dimensional analysis is required.

Employing the usual assumptions of first order, two-group perturbation theory, an expression for the reactivity introduced into a reactor system by a small perturbation (definitely applicable to the alterations in the PSR-test element system performed here) is:

$$
\begin{aligned}
\frac{\delta k}{k}= & \left\{\int\left[\phi_{i}^{*} \nu \Sigma_{f} \epsilon \phi_{2}\right] d v\right\}^{-1}\left\{\int \left[\phi_{i}^{*} \nu \delta\left(\Sigma_{f} \epsilon\right) \phi_{2} .\right.\right. \\
& +\phi_{2}^{*} \delta\left(p \Sigma_{1}\right)_{\phi_{1}}-\phi_{2}^{*} \delta\left(\Sigma_{2}\right) \phi_{2}-\phi_{1}^{*} \delta\left(\Sigma_{1}\right) \phi_{1} \\
& \left.\left.-\nabla \phi_{2}^{*} \cdot \delta\left(D_{2}\right) \nabla \phi_{2}-\nabla \phi_{1}^{*} \cdot \delta\left(D_{1}\right) \nabla \phi_{1}\right] d V\right\}
\end{aligned}
$$

where the integrals are performed over the reactor system, $\phi *$ and $\phi$ are unperturbed adjoint flux and flux respectively, epithermal parameters are denoted by 1 , and thermal parameters are denoted by 2 . Many of the changes of parameters which appear above are relatively easy to calculate and one, $\delta p$, may be obtained from other measurements discussed in this report. The two changes of diffusion constants $\delta D_{1}$ and $\delta D_{2}$ are perhaps the most difficult to calculate and their value is not given directly by the experimental results. The method of analysis suggested here is the following:

1. Determine $\phi$ and $\phi^{*}$ by a group-diffusion theory, three dimensional computer code for the unperturbed PSR-test element system. 
2. For the desired perturbation, calculate or surmise from experimental results all changes in parameters except $\delta 0$.

3. Either estimate one $\delta D$ (probably. $\delta \mathrm{O}_{2}$ ) and find the other $\delta D$ by requiring $\delta k / k$ to assume the measured value, or, $f i x$ a relation between $\delta D_{1}$ and $\delta D_{2}$ and solve for both.

4. The relatively simple parameter changes introduced by the indium calibration can be calculated and should be compared with the equivalent measurement.

Once all the parameter changes for a given perturbation are determined, these same parameter changes with the $\phi *$ and $\phi$ and $\nabla \phi^{*}$ and $\nabla \phi$ of the CRBR used in the expression for $\delta k / k$ will yield the reactivity changes for the CRBR system.

\section{CONCLUSIONS}

This set of experiments has been useful in verifying and adjusting the theoretical calculations of the resonance escape probability, through the evaluation of the macroscopic resonance cross section, and the lattice thermal utilization, by comparison of measured average fluxes with those obtained by $\mathrm{P}_{3}$ methods. Similarly, reactivity effects caused by changes - in moderation have been correlated with theoretical predictions.

The limitations of experiments of this type, where small samples are used in dissimilar lattices, are that the analysis of results is more difficult, less accurate, and requires more assumptions than measurements made in a full lattice (critical or exponential). These Iimitations were recognized from the inception of the experiments, but, because of the simplicity and economy of the measurements, they were not felt to be restrictive. 
It may be generally concliuded that small sample measurements of this type can be used with success to obtain certain lattice parameters, and specifically concluded that reliable information pertinent to the evaluation of nuclear parameters (resonance escape, thermal utilization, reactivity effects) of various CRBR lattices has been obtained. 


\section{APPENDIX A}

\section{SEPARATION OF URANIUM FROM ITS FISSION PRODUCTS BY THE SODIUM URANYL ACETATE METHOD}

1. Dissolve the uranium foil in concentrated, boiling nitric acid. When the uranium sample is completely dissolved (in the present case this requires about 10 minutes), the remaining acid should be evaporated leaving an orange powder (uranyl nitrate).

2. Add at most $50 \mathrm{mi}$ distilled water for each gram of uranium dissolved. It is probably necessary to heat this solution to completely dissolve the uranyl nitrate.

3. From the solution obtained in step 2, pipette by syringe $6 \mathrm{ml}$ to a small beaker and add $2 \mathrm{ml}$ glacial acetic acid. Heat this solution to evaporate to $1 \mathrm{ml}$ (this requires about 15 minutes).

4. To this solution add $2 \mathrm{ml}$ of $1 \mathrm{M}$ acetic acid and transfer the solution to a centrifuge tube. Add $2 \mathrm{ml}$ of $1 \mathrm{M}$ sodium acetate and shake. A precipitate should begin to settle at this point. If not, warm gently to concentrate the solution.

5. Add $5 \mathrm{ml}$ of $5 \mathrm{M}$ sodium nitrate. Cool in ice water, and, centrifuge for about one minute.

6. Pour off the supernate and a yellow precipitate will remain at the bottom of the centrifuge tube. If only one sample dissolution is desired skip step 7 and continue with step 8 .

7. If a double sample dissolution is desired, dissolve the precipitate by adding two to four drops of concentrated nitric acid and warming. Repeat 4-6 except add on ly $\mid \mathrm{ml}$ of $\mid \mathrm{M}$ acetic acid and $\mid \mathrm{M}$ sodium acetate and $2.5 \mathrm{ml}$ of $5 \mathrm{M}$ sodium nitrate. All this to be done in the centrifuge tube. 
8. Using alcohol wash the precipitate from the centrifuge tube onto a filter paper. Then wash the yellow filtrate with a small amount of cold alcohol or cold ether.

9. Dry the powder on the filter paper and then scrape into a small beaker. This yellow powder is sodium uranyl acetate and should be about .05 to .15 grams. Three $\mathrm{ml}$ of water will dissolve this amount. In the present work, $2.8 \mathrm{ml}$ of distilled water was used to dissolve the filtrate and then this solution was placed in a planchet $0.5 \mathrm{~cm}$ deep and one inch in diameter. The liquid was then counted as illustrated in Figure 6. 


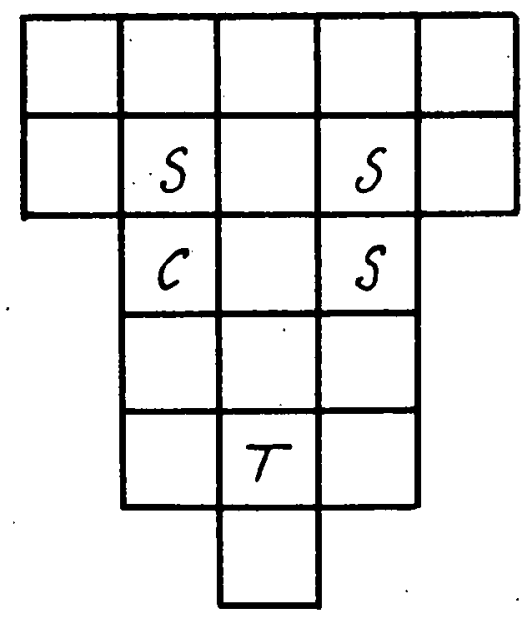

PSR CORE A

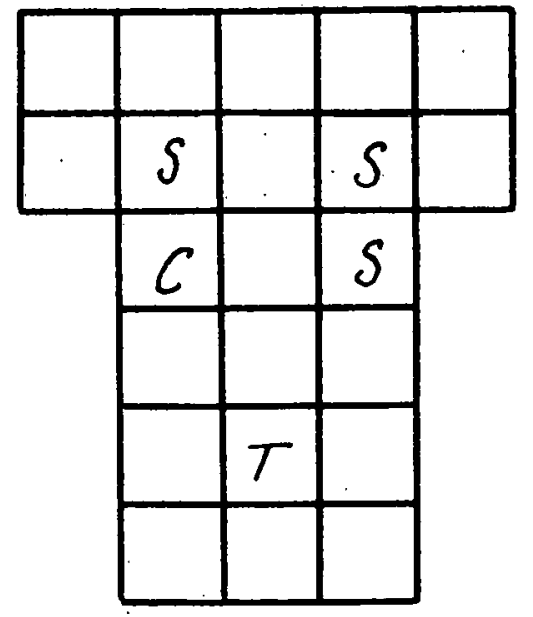

PSR CORE B

FIGURE I. PSR CORE CONFIGURATIONS

$S$ : safety rod element

C: control rod element

$T$ : test element 

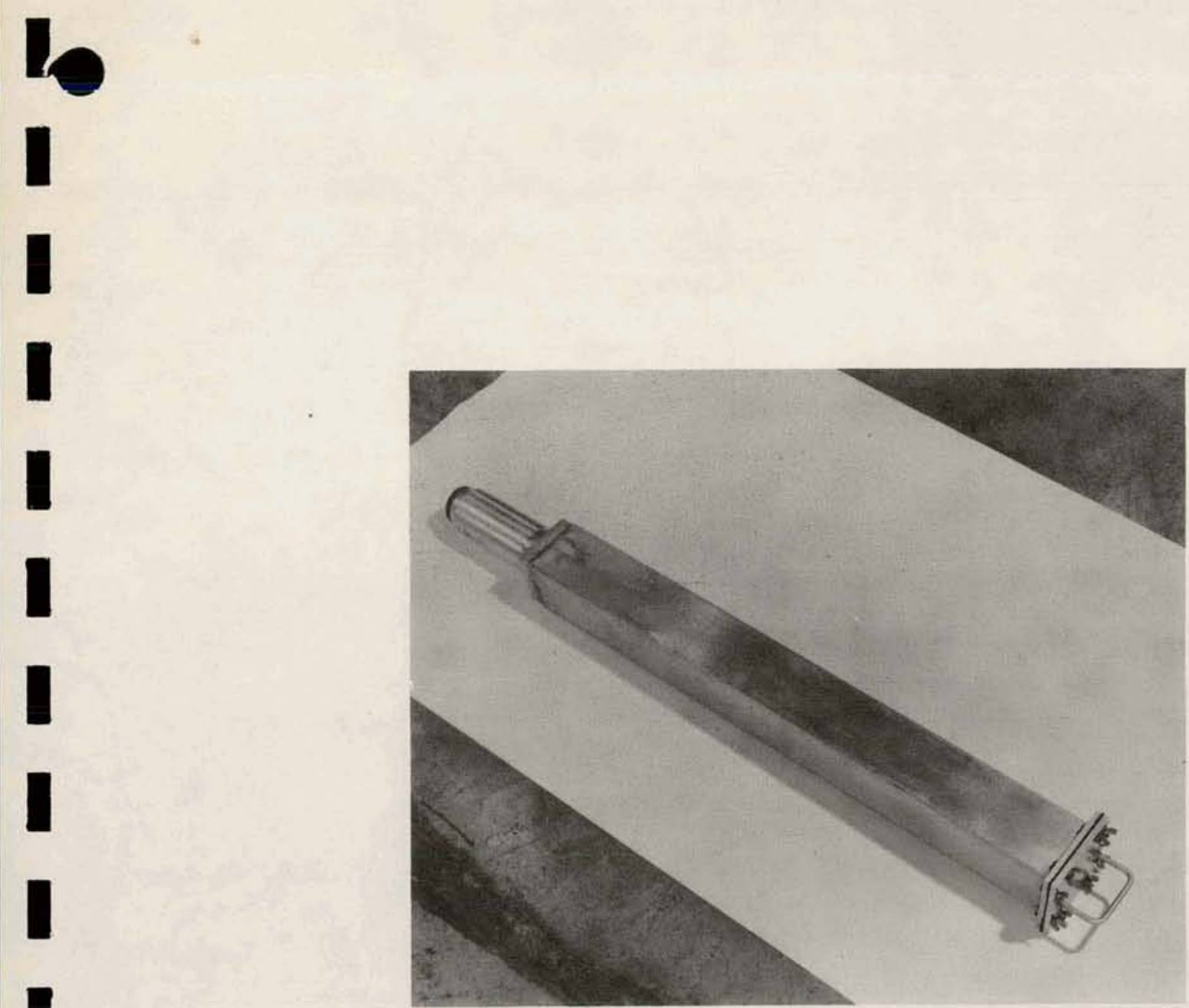

FIGURE II. TEST ELEMENT CAN 


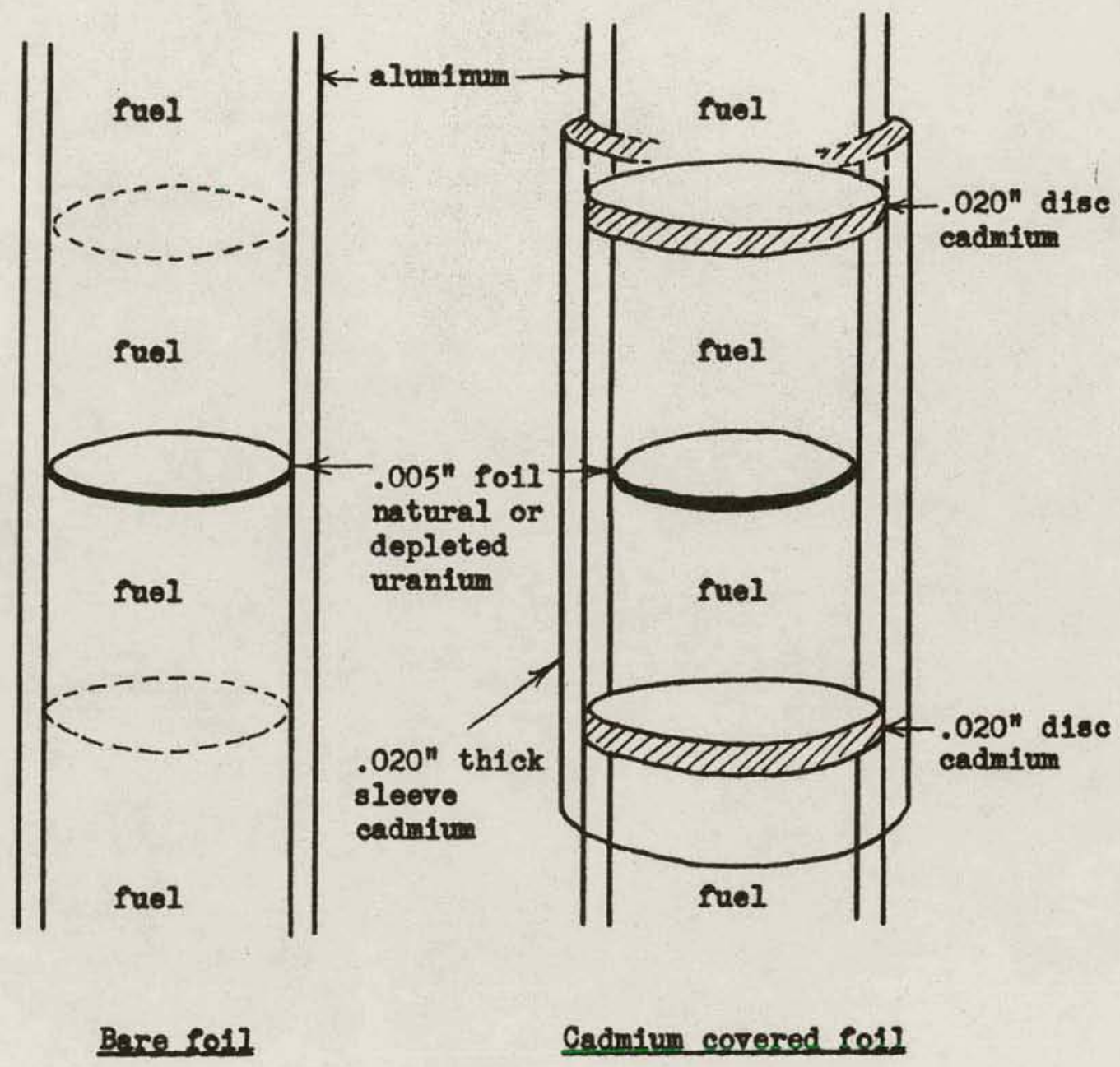

FIGURE III. ARRANGEMENT OF FOILS FOR R MEASUREMENT 


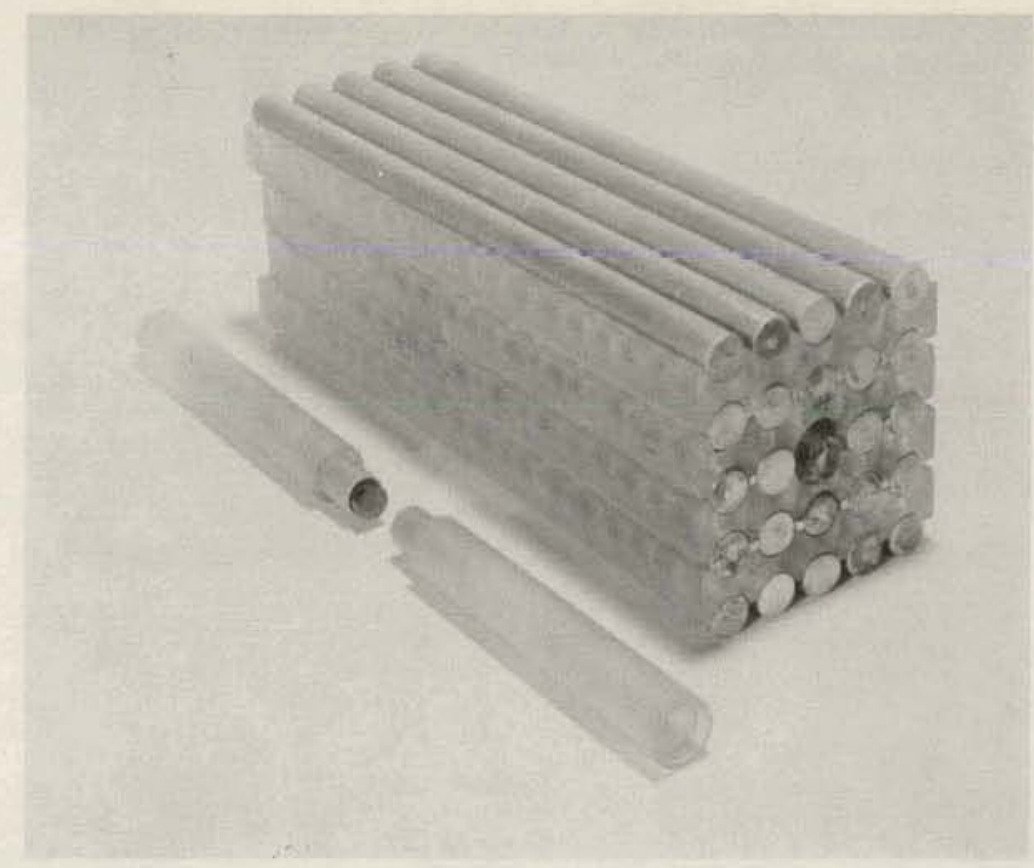

FIGURE IV. BOILING WATER LATTICE TEST SECTION

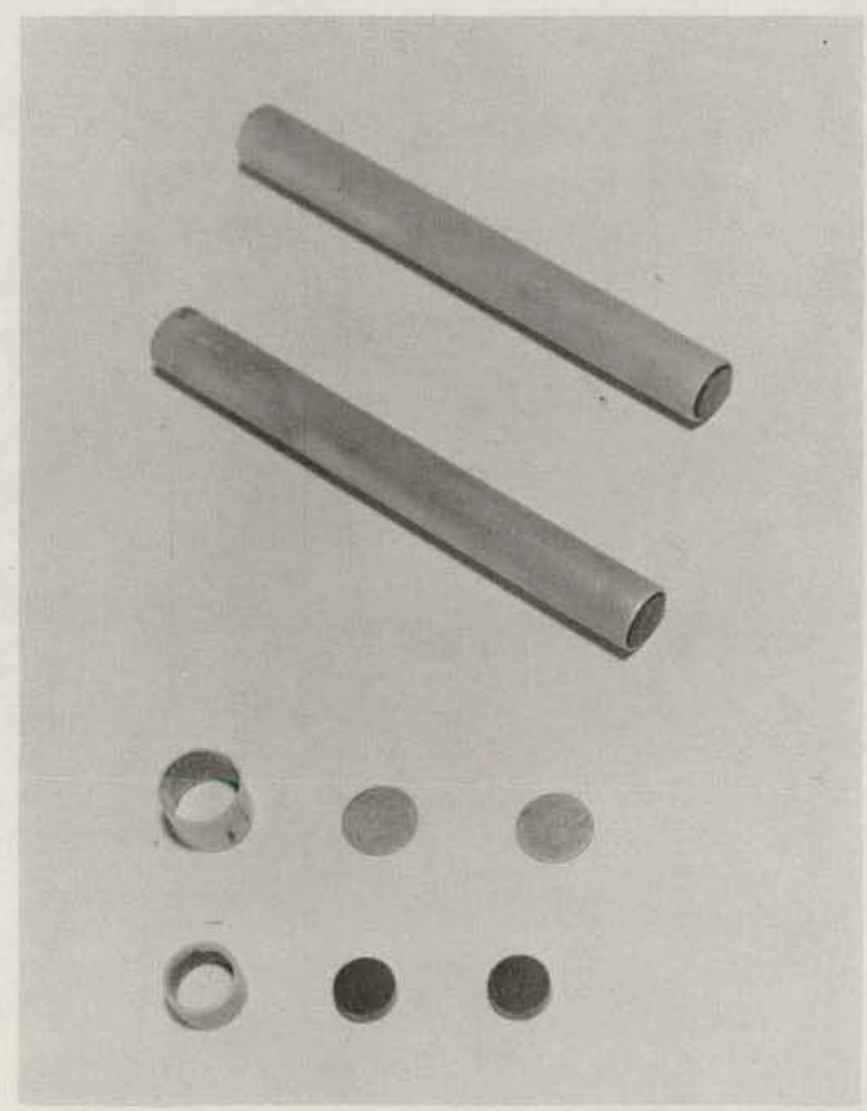

FIGURE V. BOILING WATER LATTICE FOIL HOLDING PIN AND ASSEMBLY 


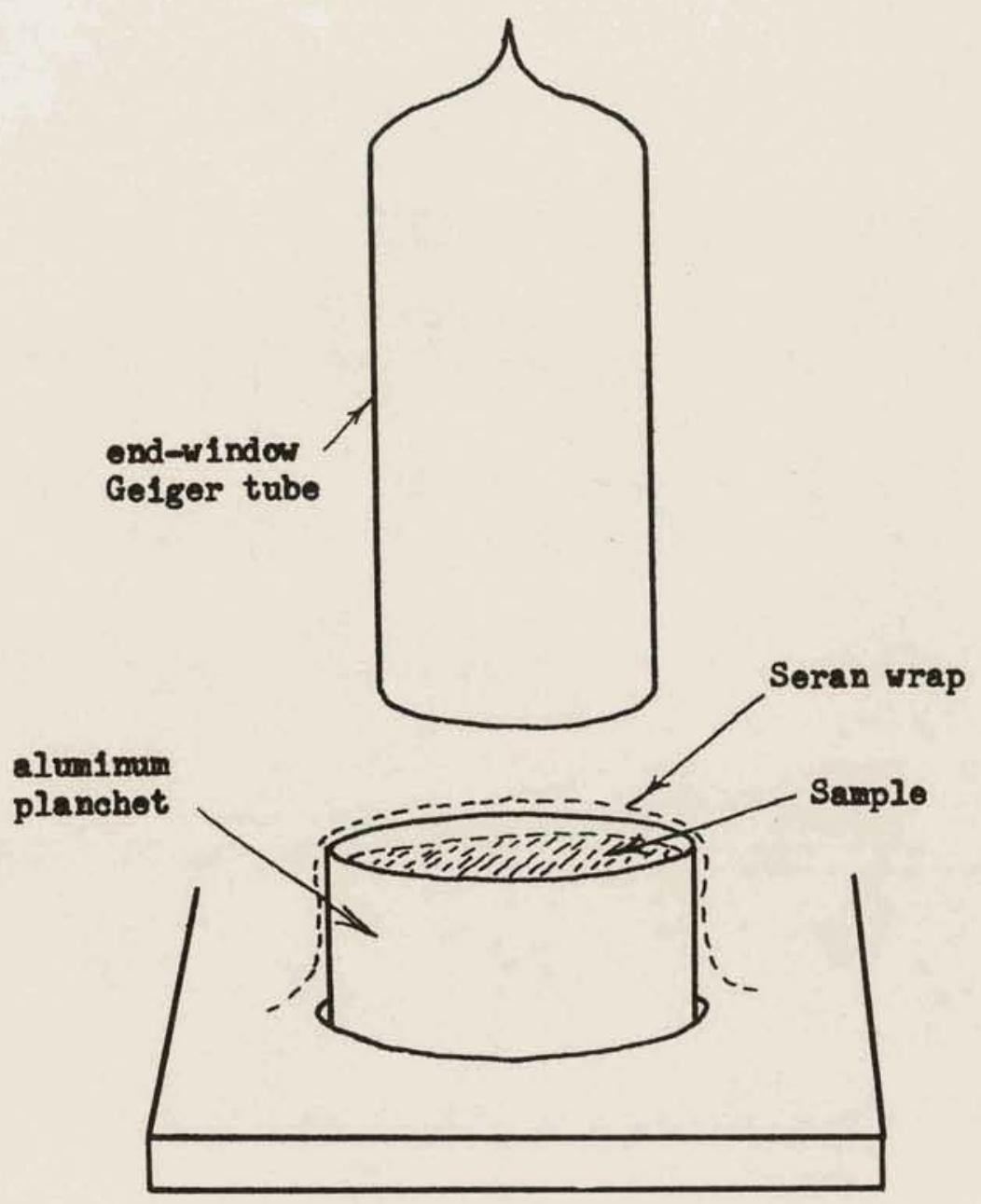

FIGURE VI. BETA COUNTING CONFIGURATION 


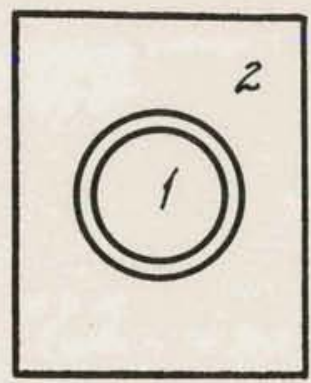

\author{
Bolling reter lattice \\ Foi1 tho. \\ Lattice section \\ Dimensions \\ 1 \\ Trel \\ $.87 \mathrm{~cm}$ OD \\ moderator \\ $1.13 \mathrm{~cm}$ ID \\ $1.59 \times 1.35 \mathrm{~cm}$
}

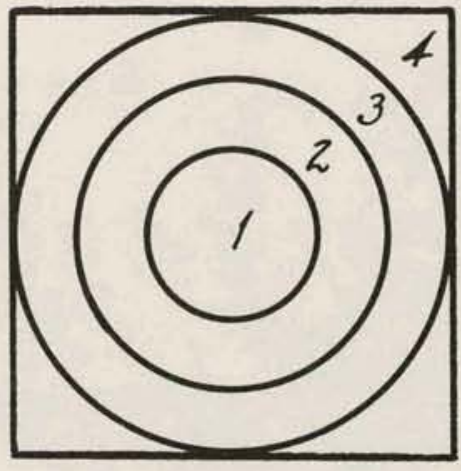

Low emcichment superheater lattioe

Fo11 No.

Iattice section

Dimensions

1

stean

$1.70 \mathrm{~cm}$ OD

ruel \& stl clad

2.550m OD

steam \& stl tube

$3.35 \mathrm{~cm}$ OD

3 moderator

$3.35 \times 3.35 \mathrm{~cm}$

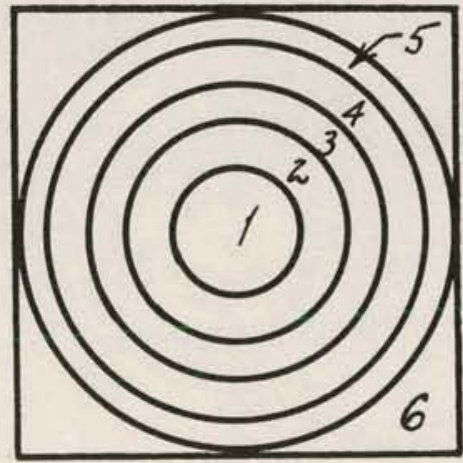

High emplehment superheater lattice

Fo11 No.

Lattice section Dimensions

1

Inner fuel \& steam

$1.00 \mathrm{~cm}$ OD etr fuel \& stean

$1.70 \mathrm{~cm}$ OD

2

outer fuel \& stean

$2.30 \mathrm{~cm} O D$

outer steam

$3.00 \mathrm{~cm}$ OD

4

steel tube

$3.35 \mathrm{~cm}$ OD

moderator

$3.35 \times 3.35 \mathrm{~cm}$

FIGURE VII. FOIL SECTIONS FOR THERMAL NEUTRON FLUX MEASUREMENTS 

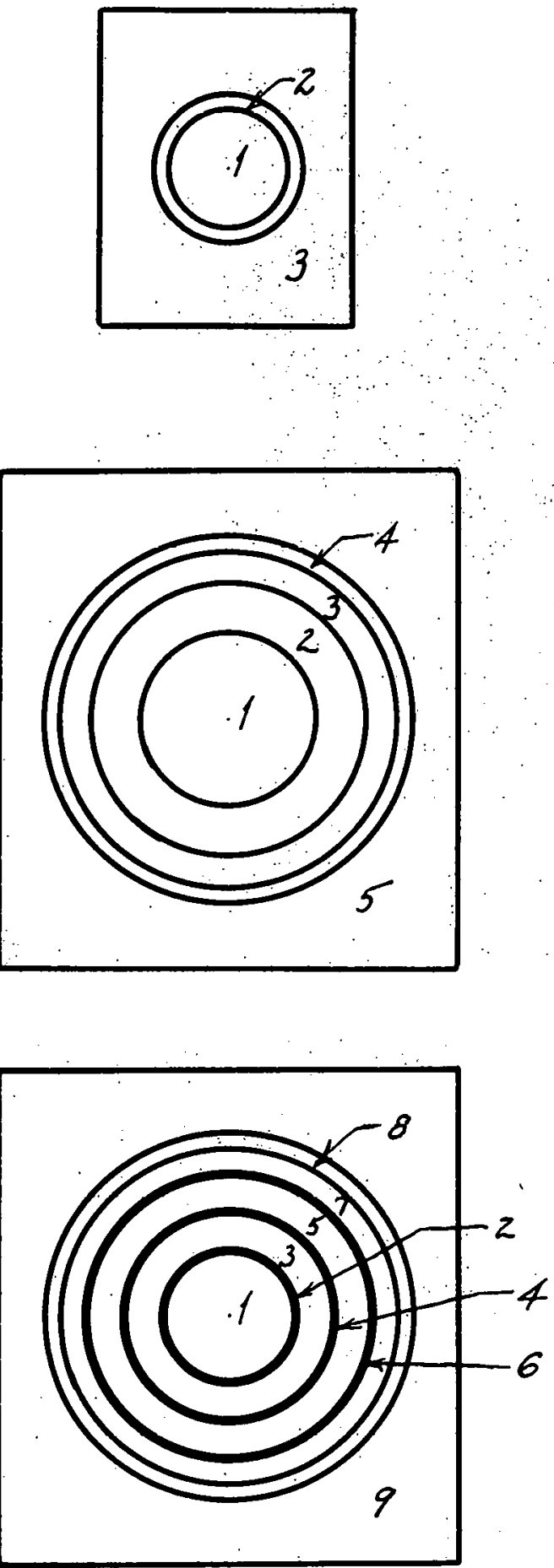

\section{Boplineivater latt1os}

Section

yotortal

Dimenstons

1

$\mathrm{DO}_{2} 1.6 \% \mathrm{e}$

$.359^{\circ}$ OD

$7 / 16^{\prime \prime}$ OD

$.035^{\prime \prime}$ vall

3

Incito
Low enclehment superbester_lattice

Section

Yoterfel

Dimeneion:

$\frac{1}{2}$

4

sti

Vold $\mathrm{DO}_{2} 1.6 \% \mathrm{e}$

8 otl-304 clad

Void

5 $.650^{n} \mathrm{OD}$

$.960^{n}$ OD

$.690^{\prime \prime}$ ID $.015^{\prime \prime}$ clad

$25 / 16^{n}$ oD $1 / 16^{\prime \prime}$ vall

$122 / 32 \times$

$117 / 32^{n}$

\section{E1 gh enclchment superheater latt1eg}

Sect1on
$1,3,5,7$
$2,4,6$
8
9

Material

Dimepsion:

Vold

- ot $1-\mathrm{DO}_{2}$ cermet 2: .389n ID

$180 \% 00_{2} 20 \%$

$48.634^{\prime \prime}$ ID

6: $.880^{n}$ ID

all .029" vall

s st1

$15 / 16^{n}$ OD

$1 / 16 "$ wa11

Ineite

$122 / 32 x$

$117 / 32^{n}$

FIGURE X. UNIT LATTICE CELL DIMENSIONS AND SPECIFICATIONS 


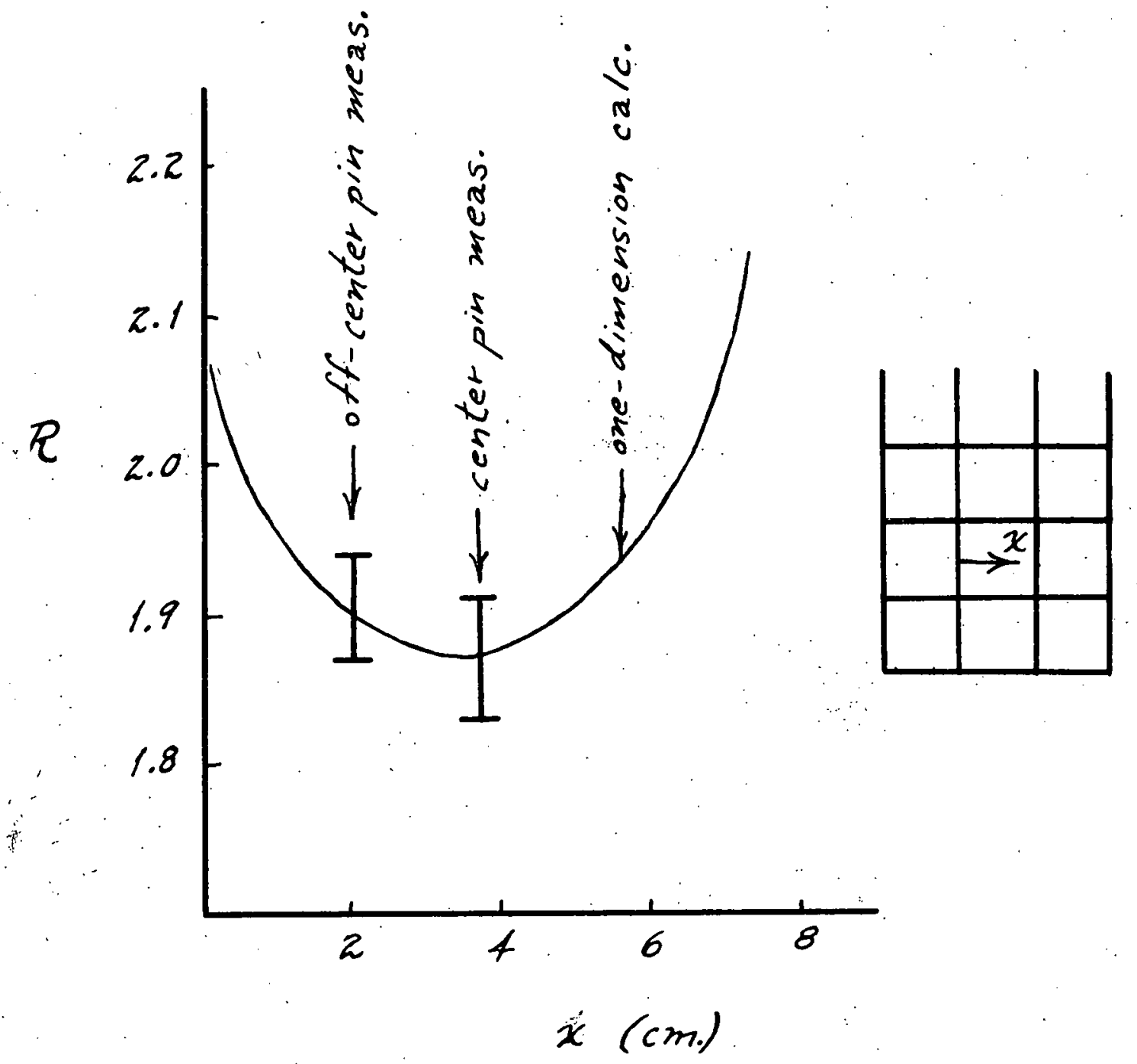

FIGURE XI: COMPARISON OF MEASUREMENT AND CALCULATION OF CADIUM RATIO, R. FOR THE BOILING WATER LATTICE

Values of $x$ between 0 and $7.3 \mathrm{~cm}$ are within the test element. The uranium-238 resonance group cross-section of $.082 \mathrm{om}^{-1}$ was used in the calculation. Th1s value was used to reproduce the center pin measurement. 


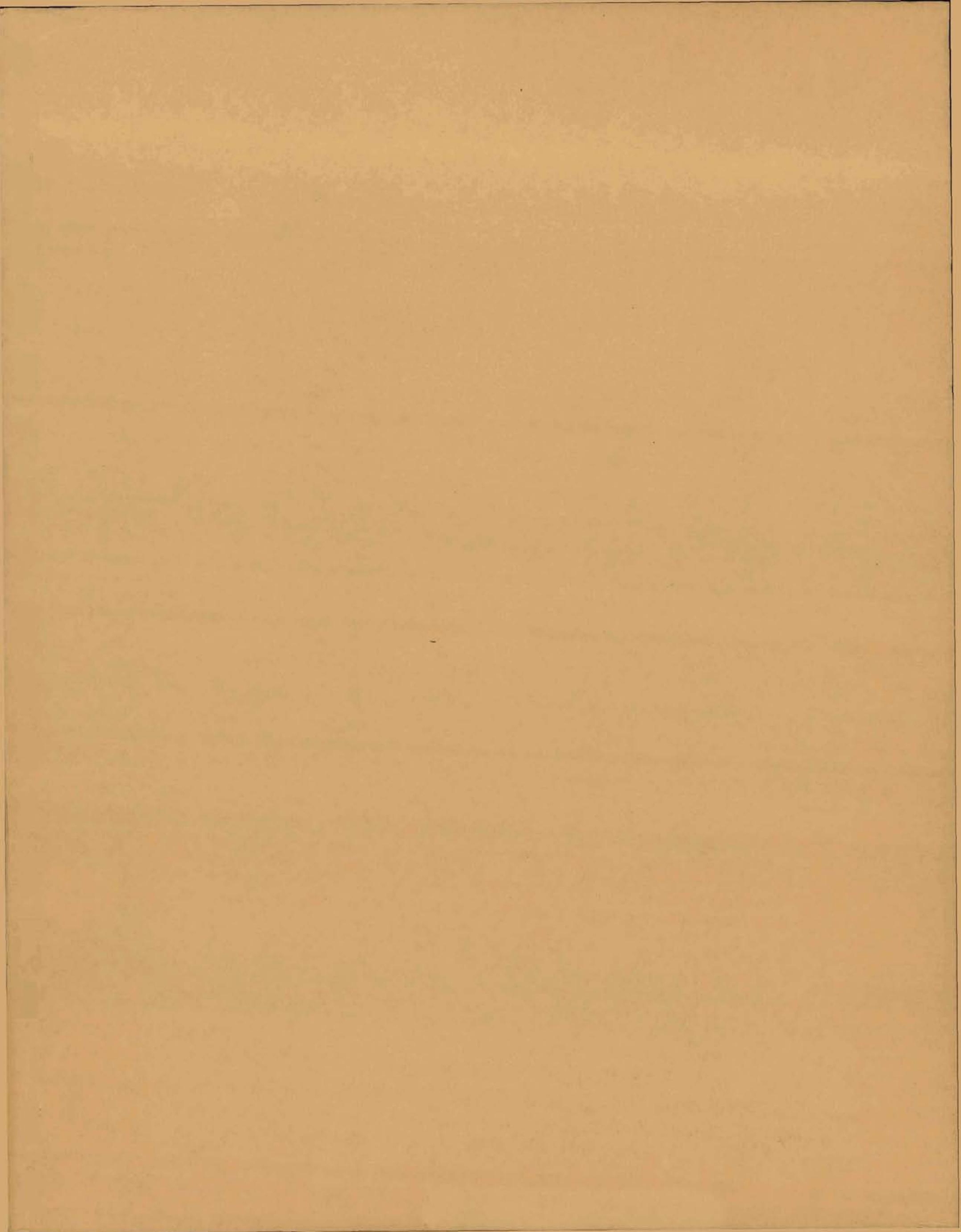

